\title{
BENETTI, Rosalice Carriel. Vladimir Kozák: sentimentos e ressentimentos de um “lobo solitário”. Curitiba: SAMP, 2016, 272 páginas.
}

Adriane dos Santos Tavella Ferrari ${ }^{1}$

- Enviado em 13/05/2017

- Aprovado em 28/06/2017

Resultado da sua dissertação de mestrado no Programa de Pós-Graduação em História da Universidade Federal do Paraná, o livro de autoria de Rosalice Carriel Benetti é dedicado ao imigrante tcheco, Vladimir Kozák, nascido em 1879, radicado no Brasil desde 1924 e falecido em 1979.

Ao pesquisar sobre a trajetória de Vladimir Kozák, a autora faz uma análise reflexiva do conjunto de sua correspondência pessoal entre o período de 1938 a 1978, tendo como objetivo interpretar a trajetória social do personagem durante essa fase de sua vida. Segundo Benetti essa análise, possibilitaria, dar voz e visibilidade ao destinatário e aos seus correspondentes, traçando assim, seus laços de amizade, paixões, ressentimentos e mágoas que interferiram nas suas relações pessoais e profissionais. A pesquisa foi realizada no arquivo pessoal de Vladimir Kozák ${ }^{2}$ com ênfase na documentação epistolar, que possui aproximadamente três mil e trezentas cartas, trocadas com pelo menos duzentos e setenta correspondentes e em diversos idiomas (tcheco, inglês, português, alemão e espanhol) sobre diversos assuntos tais como: compras, pesquisas de material fotográfico, pagamento de material, doações para refugiados da Segunda Guerra Mundial entre outros.

\footnotetext{
${ }^{1}$ Graduada em Ciências Sociais pela Universidade Federal do Paraná. Especialista em Antropologia Social pela PUC/PR. Endereço eletrônico: adrianeferrari2045@gmail.com

${ }^{2}$ Hoje pertencente ao acervo do Museu Paranaense.
} 
A divisão do livro constitui-se em três capítulos: o primeiro capítulo intitulado "Algumas considerações sobre os arquivos ", o segundo "Vladimir Kozák" e o terceiro "Os sentimentos revelados nas cartas".

O primeiro capítulo denominado "Algumas considerações sobre os arquivos" traz reflexões sobre os arquivos, correspondências pessoais e a "escrita de si" (memórias, diários, cartas e escritos produzidos em primeira pessoa). Nesse capítulo a autora trata da questão metodológica e do desafio de pesquisar em uma documentação epistolar. A questão central é como utilizar arquivos e correspondência pessoais como fonte de pesquisa sem deixar de lado a necessidade de uma observação criteriosa de diversos aspectos dos documentos e de suas particularidades. Finaliza destacando a importância do inventário de correspondências de Vladimir Kozák e como o intenso fluxo de comunicação possibilitou a investigação do que foi escrito revelando assim, um universo de discursos e práticas do autor possibilitando identificar aspectos da trajetória do personagem.

No segundo capítulo intitulado "Vladimir Kozák" a autora traça cronologicamente seu percurso biográfico indicando os momentos mais significativos de sua via segundo aponta o próprio Kozák na documentação pesquisada (cartas, diários ou anotações avulsas). Formado em engenharia mecânica na Escola Nacional Tcheca de Brno (capital da Morávia) e em Escultura e Pintura em Purkyne University, no Departamento de Arquitetura, Kozak chega Brasil em 1924 aos 27 anos. Trabalhou em Vitória, Salvador e Belo Horizonte antes de chegar em Curitiba no ano de 1938 e fixar-se na cidade. Era engenheiro da Companhia de Luz e Energia do Paraná (COPEL) e no ano seguinte, em 1939, sua irmã Karla Kozák vem para o Brasil e passa a residir com ele. Paralelo ao seu trabalho como engenheiro, em seu tempo livre, fazia o registro de paisagens e da natureza do Brasil.

Em 1946, Loureiro Fernandes, então diretor do Museu Paranaense convida Kozák para coordenar a Seção de Cinema da instituição, função que exerceu até 1963 como "assistente voluntário " devido ao a questões burocráticas por ser estrangeiro. Vladimir tinha uma grande importância para as pesquisas do Museu Paranaense pois, incentivou a ampliação das ações e pesquisas da instituição com a utilização do filme e da fotografia visto que possuía equipamentos próprios e tinha conhecimento técnico. Muitas vezes, com seus próprios recursos, custeou ou adiantou o pagamento de despesas que seriam de responsabilidade do Estado. Em 1952 por 
interesse pessoal e influência de Loureiro Fernandes foi nomeado para a função remunerada de cinetécnico da Universidade Federal do Paraná. Em 1963 foi convocado para exercer a função de diretor do Museu Paranaense, porém recusou alegando "motivos particulares".

Kozák durante suas férias como engenheiro mecânico da Companhia de Luz do Paraná, emprego que garantiu sua subsistência e onde permaneceu até se aposentar ${ }^{3}$. Sua primeira incursão a uma aldeia indígena foi no Espírito Santo durante o de 1942. Depois, em 1948 visitou Mato Grosso. Sempre registrando através de fotos e filmes os aspectos da cultura indígena. No período de 1956 a 1961 filmou e fotografou os Xéta na Serra de Dourados, no noroeste do Paraná. Um extenso trabalho que teve mais de 20 visitas.

Outra questão muito importante destacada pela autora neste segundo capítulo é que a produção de fotos e filmes de Kozák revela em cada detalhe que ele sempre estava atento as inovações tecnológicas de sua época. A sua percepção dos grupos indígenas ocorria por meio das imagens sendo poucas as anotações em diários de campo. As questões acadêmicas ou científicas nunca foram sua preocupação. O seu interesse pela fotografia tornou-se um exercício contínuo e ininterrupto, sendo ela a linguagem adotada para expressar e expor seus sentimentos em relação aos grupos indígenas, as paisagens, o folclore brasileiro e outros temas por ele abordados. A sua intensa relação de Kozák com as imagens também é percebida através de sua produção fílmica em que segundo Benetti "filmar para ele foi uma empreitada pessoal pois, trabalhava sozinho, exercendo o papel de idealizador, roteirista, produtor, cinegrafista, diretor e editor de todos os filmes que produziu" (página 134). Também retratou diversas imagens em aquarelas e esboço de crayon para depois fixá-las em pastel ou óleo. Algumas de suas pinturas a óleo e aquarelas foram expostas em diversas localidades no Brasil.

Os diferentes objetos que coletava durante suas viagens faziam parte de seu acervo particular. Suas expedições eram realizadas com recursos próprios e não tinham apoio financeiro nem do Estado ou de qualquer outra instituição privada. Após sua morte repentina e inesperada seu acervo ficou sob a responsabilidade do Museu Paranaense e encontra-se disponível para pesquisa que são incentivadas pela instituição para dar mais visibilidade à obra de Kozák e ele poder obter reconhecimento pelo seu trabalho.

\footnotetext{
${ }^{3}$ Não há referências do ano em que Kózak filmava e produzia documentários viajando pelo interior do Brasil.
} 
No último capítulo, "Os sentimentos revelados nas cartas", a autora destaca a importância das cartas de Kozák na revelação de suas redes de relações pessoais, sociais e profissionais, assim como possibilitam perceber seus sentimentos em relação aos diversos temas abordados. Kozák pode ser considerado como uma pessoa solitária que não constituiu família tendo como único laço afetivo sua irmã Karla. Em algumas cartas revela suas frustrações profissionais ao relatar a um amigo as dificuldades de apoio financeiro para suas viagens e quais foram eram as possíveis soluções para amenizar essa questão como por exemplo, pedir ajuda a Força Aérea do Brasil para seu transporte e de seu material coletado.

As correspondências de Kozák nos revelam que ele tinha um círculo reduzido de amizade, mantinha um diálogo íntimo e intenso com algumas pessoas selecionadas com quem dividia os mesmos interesses, preocupações e sentimentos. Essas escritas revelam muito de si e dos outros.

Entre esse restrito círculo de amigos destaca-se o casal de antropólogos que viviam nos Estados Unidos, "Bob e Trudie". A troca de correspondência entre ele tratando de suas experiências de viagens e pesquisas iniciou em 1953 e foi até sua morte em 1979. O casal conheceu Kozák em uma viagem para o Alto do Xingu em um avião da Força Aérea Brasileira. Ficaram impressionados com o seu conhecimento e sua excelente documentação fotográfica sobre os índios. Esse diálogo por cartas facilitou contatos, deslocamentos e pesquisas para ambos os lados. Nas cartas há muita insistência do casal em afirmar o valor e reconhecimento de trabalho de Kozák fora do Brasil.

Outra correspondente de destaque era Marjory Baillon, canadense, amiga com quem compartilhava uma certa afinidade intelectual e mantinha um diálogo mais intimista demonstrando sentimentos e ressentimentos comuns. Teriam se conhecido em Curitiba, mas não há mais detalhes e referências desse encontro. A autora destaca que o conteúdo do conjunto da troca de correspondências entre Kozák e Marjory, demostra como a amiga emitia opiniões em aspectos mais pessoais, como saúde, finanças, realização pessoal e profissional, sendo possível constatar que a presença de Marjory foi bem expressiva na vida de Kozák demonstrando um relacionamento entre eles muito particular e um forte elo de amizade.

Com quase todos os correspondentes Kozák partilhava de uma mesma afinidade intelectual - esse é o tema mais recorrente revelado na análise de suas correspondências. Havia 
também uma grande troca de ideias, demonstrações de cuidados e respeito recíproco, compartilhamento de diversos sentimentos como alegrias, tristezas, aflições, dificuldades, opiniões, sucessos e insucessos. A autora conclui que a grande importância das cartas está em revelar os modos de pensar e agir de Kózak e trazem à tona uma série de questões que afetaram positiva ou negativamente sua vida e a de seus amigos correspondentes. A importância do arquivo pessoal, do testemunho dos fragmentos e dos vestígios recolhidos no acervo de Kozák trouxeram a possibilidade de se pensar a amizade como uma via de acesso para traçar a trajetória do personagem e suas relações. 